\title{
Multiple Pulmonary Metastases of Giant Cell Tumor of Bone with expression of VEGFR-2 Successfully Treated by Denosumab and Apatinib: A Rare Case Report
}

\section{Case report}

Keywords:

Posted Date: March 30th, 2021

DOI: https://doi.org/10.21203/rs.3.rs-221200/v2

License: (1) This work is licensed under a Creative Commons Attribution 4.0 International License. Read Full License 


\section{Abstract}

The authors have requested that this preprint be withdrawn due to erroneous posting.

\section{Full Text}

The authors have withdrawn this preprint from Research Square. 